\title{
Article \\ From Oral to Written Dakwah: A Study on the Development of Preaching Methods in Indonesia
}

\author{
Safei Agus Ahmad \\ Fakultas Dakwah dan Komunikas, UIN Sunan Gunung Djati, Jawa Barat 40614, Indonesia; gussgduin@gmail.com
}

\begin{abstract}
Musabaqah Tilawatil Qurân (MTQ/Al Quran Reciting Competition) is often regarded as a big and important momentum for the process of Islamic preaching in Indonesia. It has even become a tradition for Indonesian people, although Al-Quran reciting is a common activity and a universal phenomenon in the Islamic world. In the MTQ event, the participants compete at various fields, including Tilawah (the art of reciting Al-Quran), Fahmil Qurân (comprehension of Al-Quran contents), and hifzul Qurân (memorization of Al-Quran verses). In 2003, a new field was initiated in the MTQ competition; i.e Musabaqah Makalah Ilmiah Al-Qurân (M2IQ/Al-Qurân Academic Writing Competition). Since its first exhibition on the 2003 Regional MTQ in West Java Province, and later on the 2008 National MTQ, the M2IQ, which is based on written-preach (dakwah bilkitabah), is considered as an innovation of preaching method in Indonesia. Islamic preaching (dakwah) in Indonesia has always been leaning heavily on the oral-preaching (dakwah bilisan) method, as represented by other fields contested in an MTQ. This development warrants a comprehensive study to understand what considerations underlying the emergence of M2IQ, how the process is, and what contributions it provides to the development of Islamic preaching in Indonesia. This study utilizes analytic-descriptive approach to discover the phenomenon. The findings indicate that M2IQ has accentuated the intellectual aspect of MTQ. In addition, M2IQ widens the spectrum of Al-Qurân preaching in Indonesia; opening a new chapter of Islamic preaching (dakwah) in the country.
\end{abstract}

Keywords: development; methods; oral preaching; written preaching; Dakwah; innovation

\section{Introduction}

Musabaqah Tilawatil Qurân (MTQ/Al-Qurân Reciting Competition) is a media of spreading Islam to wider society. It is conducted in levels, from the local village to national level, once every two years. The spirit of competition (musabaqah) generated by MTQ is expected to stimulate the public to read, understand, and practice Al-Qurân's contents in their own surroundings.

Since the first National MTQ in 1968 until today, the fields and categories contested in the competition are continuously developed. Moreover, since the founding of Lembaga Pengembangan Tilawatil Qurân (LPTQ/ Al-Qurân Reciting Development Body) in 1977, MTQ is directed as one of the media to realize the implementation of Al-Qurân in public's daily life.

Historically, since 1968, MTQ is institutionalized in national level. The first MTQ was held in Makassar in 1968. It only involved adults as participants of the competition. The winners of the first MTQ are Qari Ahmad Syahid from West Java and Muhammadong from South Sulawesi. In 2014, National level MTQ has been held 27 times.

Based on Pedoman Musabaqah Al-Qurân (the Manual of MTQ; LPTQ, 2010: 14-15), there are seven fields or categories being contested in the MTQ: Tilawah Al-Qurân (reciting Al-Qurân), Hifzh Al-Qurân (memorization of Al-Qurân verses), Tafsir Al-Qurân (interpretation of Al-Qurân), Fahm Al-Qurân (Al- 
Qurân comprehension), Syarh Al-Qurân (explanation of Al-Qurân), Khat Al-Qurân (calligraphy), and Musabaqah Makalah Ilmiah Al-Qurân (M2IQ/ Al-Qurân Academic Writing Competition).

From the perspective of dakwah (Islamic preaching), MTQ is a big and important momentum for the processes of diffusion, transmission, transformation, and internalization of Islamic teaching. All the fields being contested in the competition are regarded as media to spread Islam and as stimulus that are expected to affect people to further the process of spreading Islam.

On the other hand, MTQ is also considered a part of the process to develop the skills, comprehension, and methods needed for dakwah. One of the methods or media for dakwah that has been a weakness of Islamic community, particularly in Indonesia, is the written method. Writing tradition, in Islamic community, is far from being developed; while the development of written (printed) media happens so rapidly and so dynamic.

On the last few MTQs, Al-Qurân is introduced not only through, and on, the aspects of recitation, interpretation, and explanation, but also the aspect of writing. All these aspects are developed with the hope that they can improve public positive attitudes toward Al-Qurân, which in turn will result in greater and deeper psychological impacts in every Moslem individual.

One of the fields in which the participants compete in MTQ since 2003, particularly in the regional level of West Java Province, is Musabaqah Menulis Kandungan Al-Qurân (M2KQ/ Al-Qurân Contents Writing Competition). When it was first officially brought to the National level, in 2010, its name was changed into Musabaqah Makalah Ilmiah Al-Qurân (M2IQ/ Al-Qurân Academic Writing Competition). This field integrated two skills or capabilities in one competition: the technical skill to write and the academic intelligence. Therefore, the quality, capacity, and perception of the participants of M2IQ are seriously challenged. This field is expected to produce the next generation of Moslem writers whose works will become sources of enlightenment for people in the future.

M2IQ brings new colors and nuances to the history of MTQ in Indonesia. It revitalizes MTQ that has always been representing the oral tradition of Islamic teaching. M2IQ reminds us about the importance of rejuvenating the tradition of writing that has been abandoned by Islamic communities in Indonesia for centuries.

Dakwah or the spreading of Islamic teaching has always been identical with preaching, lecturing, and the likes. It is seldom that people call the activities of columnists, reporters, or other writers as dakwah. People call Kyai Arifin Ilham, who is able to make his audience cry in his preaches, a da'i (a person who does dakwah) without having to think too hard. However, the same people are unlikely to call a writer a $d a^{\prime} i$, although the writer is always involved in activities to spread Islamic teaching. Spreading Islamic teaching through writing has actually been around longer than the oral tradition of dakwah. This kind of dakwah is, in fact, a more lasting way to serve the religion.

Not only it has been around longer, written media also has an edge that oral media, including the electronic media, lack. Several studies on mass communication reveal an interesting fact concerning the effects of printed media. Written media has a great influence over public behaviors. Its psychological effects are more permanent than other mass media.

Thus, the messages in written or printed media are generally have greater effects than those of oral media. A communication survey indicates that the messages contained in a book (a novel, comic books, et cetera) and magazines hold a greater psychological effect than those delivered through movies or radio that are received only through listening. One of the reasons is because printed media has a greater level of proximity to audience than the electronic media.

It shows the importance of alternative media to deliver Islamic dakwah that does not require the people to physically come to a certain venue or attend an event. One of the most effective media to do that is written or printed media. Dakwah delivered through written media can always be received by public, even when most of their time is spent for doing their daily activities. Dakwah through written media will visit people at their homes. People will still be able to enjoy Islamic dakwah without having to leave their after-dinner family meetings. 
The Musabaqah Makalah Ilmiah Al-Qurân (M2IQ/ Al-Qurân Academic Writing Competition) was first initiated by Asep Saeful Muhtadi, a professor of communication in the Faculty of Dakwah and Communication of State Islamic University Sunan Gunung Djadi Bandung. The field was first included in a regional MTQ in 2003, held in Tasikmalaya Regency, West Java Province. Five years later, in 2008, M2IQ was tested as one of the fields being contested in Nasional MTQ. It has been an official part of National MTQ since 2010, when a National MTQ is held in Bengkulu Province.

\section{Methodology}

This study attempts to describe the facts related with the emergence of Musabaqah Makalah Ilmiah AlQurân (M2IQ/Al-Qurân Academic Writing Competition) in the Musabaqah Tilawatil Qurân (MTQ/AlQurân Reciting Competition) event in Indonesia. This study aims to provide an overview of the aspects and reasons of creating M2IQ, which is considered as new innovation of dakwah method in Indonesia. The sources and respondents in this study are people who were directly and actively involved in the implementation of M2IQ. Interviews are conducted with the initiator of M2IQ, contestants from many regions, and the Islamic figures in West Java and other regions in Indonesia. This study also utilizes field observation of M2IQ implementation, in the local (regency and city) level, regional (province) level, and national level. The data is also collected using documents analysis. Data that has been collected is categorized based on the problems being studied, and is analyzed continuously from the beginning to the end.

\section{Literary Review}

More than 200 million Moslems in Indonesia express their faith in various complex ways. Greg Fealy and Sally White (2008) mentions several examples of such expression: celebrity television preachers, online fatwa services, mass religious rallies in soccer stadiums, glossy jihadist magazines, Islamic medical treatments, alms giving via mobile phone and electronic sharia banking services are just some of the manifestations of a more consumer-oriented approach to Islam which interact with and sometimes replace other, more traditional expressions of the faith.

Aside from what has been mentioned above, the expression of Indonesian Moslems is also represented in the Musabaqah Tilawatil Qurân (MTQ/Al-Qurân Reciting Competition) event. So far, there have not been many studies on MTQ. This presents great challenges as well as great opportunities to conduct a study on various aspects of MTQ. One of the few studies on MTQ was conducted by Bahrudin (2014), who examined the assessment of Tilawah (reciting) in MTQ. Another limited study was conducted by Quraish Shihab (2012), focusing on Tafsir (Interpretation). As far as the writer can tell, there has not been one study on the Musabaqah Makalah Ilmiah Al-Qurân (M2IQ/ Al-Qurân Academic Writing Competition) as a new phenomenon in the world of MTQ.

Anne K. Rasmusen (2010) conducted an interesting study concerning MTQ, particularly the field of Tilawah. Rasmusen finds that the MTQ is fun, lovely, and enjoyable for many people. The event is prepared and held seriously, in a spiritual atmosphere. MTQ is also viewed as an exercise of nationalism, because in MTQ, the representatives of every province in Indonesia parades to celebrate their own culture and ethnic tradition.

In addition, Rasmusen also find that the principles of gender equality have been applied well in the field of Tilawah (the art of reciting Al-Qurân) in MTQ. In Indonesia, women have great opportunities to be a famous soloist in the field of Al-Qurân reciting. The bi-annual event of MTQ in local and national levels provides a room for women to show their skills in front of public. This is one of the good points for Indonesian Moslem women, compared with women in other Islamic countries. There is some kind of affirmative action to accommodate the involvement of women in reciting Al-Qurân and MTQ is an important media to develop and socialize Islamic arts and culture. 
Beside Indonesia, Egypt is another Islamic country that holds MTQ. Egypt is the center of International MTQ, in which Michael Frishkopf studies Al-Qurân reciting. He notes that Al-Qurân reciting is one of the media to spread Islam in Egypt, nowadays. He further discusses about Al-Qurân reciting and explains in detail the difference between mujawwad reciting and murattal reciting from various aspects, including timbre, expression, modulation, melody, accent, pause, et cetera (Frishkopf, 2007: 10).

M2IQ indicates a new era of MTQ. This domain is expected to accentuate the intellectual aspect of MTQ, so that the event will have greater academic weighs.

The mainstream model of dakwah in Indonesia refers to the oral method. The practices of oral dakwah are easily found everywhere in the country. The domains contested in MTQ, before M2IQ, represent the methods of oral dakwah. Outside of MTQ, the practices of oral dakwah can be easily found in the society. Concerning this, Julian Millie (2008) studies the oral dakwah practices in West Java, as performed by a popular mubaligh in the area. Millie finds that the tradition of oral dakwah takes deep roots in the Moslem societies in Indonesia.

Amidst this situation, M2IQ that is based on written dakwah seems to be so contrast. On the other hand, M2IQ is expected to be a flexible and challenging media - with a wider and deeper spectrum - for young Moslems in Indonesia to produce written works. Through M2IQ, their creativity is expected to grow and develop well. Growing and developing creative culture is very valuable, which makes the media that allows such growth and development even more valuable.

M2IQ is also seen as an effort to transform dakwah through writing. In addition, it is originally intended to revive the tradition of previous ulama who explore and pour their ideas in monumental writing. The tradition of writing in the history of Islam has produced so many masterpieces.

\section{Findings and Discussion}

On the National level MTQ, up to 2014, Al-Qurân Academic Writing Competition has been held four times: in Banten Province in 2008, in Bengkulu Province in 2010, in Maluku Province in 2012, and in Riau Province in 2014. In West Java Province, the place where M2IQ was initiated, it has been held nine times by 2014; the first was in Tasikmalaya Regency in 2003, and the latest was in Kuningan Regency in 2014.

As a new driving force in the movement of dakwah in Indonesia, M2IQ is the most unique field of MTQ. One of its unique features is that the participants use typewriters to write their papers in the competition room. The initiator of M2IQ, Asep Saeful Muhtadi, explains that typewriter is choosen because it is the less expensive, the less complicated, and the safest tool to write a paper. Using typewriters allows the participants and the judges to keep the originality of the papers to the maximum. In addition, using typewriters adds a unique element to the competition.

During the competition, 50 participants will simultaneously write their papers in a great room, leaning on their own typewriters, sources of reference, tenacities, intelligence, and endurance.

Using the typewriters that they bring, each participant is given ten hours in the preliminary round, from 08.00 to 18.00 , and eight hours in the semifinal round, from 08.00 to 16.00 , to write a 10-15 pages paper. Their fingers may get blisters from typing too much, their hips may ache from sitting too long, their eyes may get tired from reading the references, but all participants do their best to finish the task at hand. One consolation for them is that they are free to regulate their own pace, to use the allocated time as they wish: when to eat, when to take a break, when to perform salat, and when to resume typing their papers. 

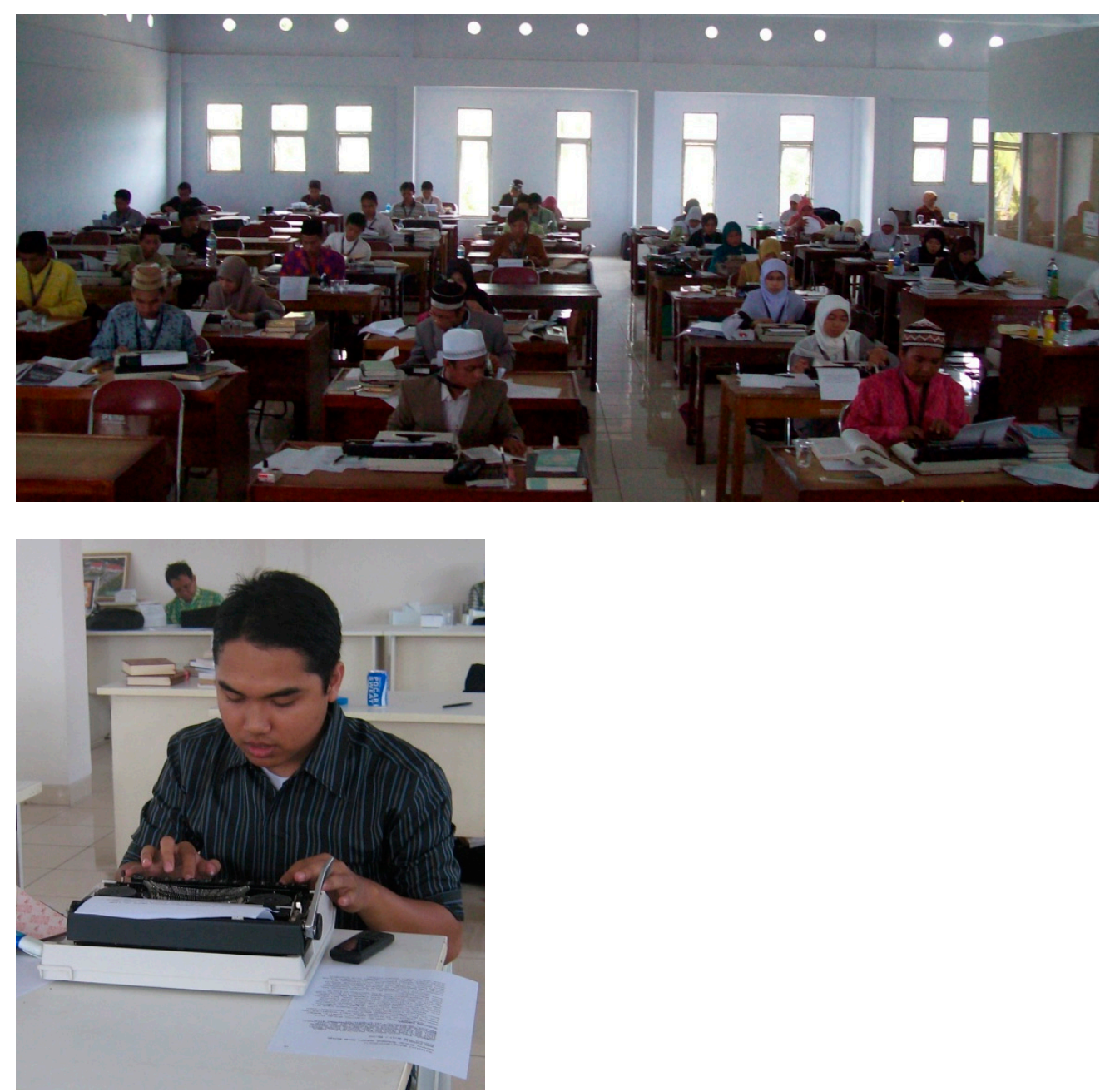

Remarks:

All participants of Musabaqah Makalah Ilmiah Al-Qurân (M2IQ/Al-Qurân Academic Writing Competition) on the National MTQ are writing articles on the content of Al-Qurân (Photo: anonymous).

The competition itself is divided into three rounds. The first round is qualification or preliminary round, the second is the semifinal round, and the third is the final round. In the first two rounds, the participants write their papers, and in the final round, they present what they have written. This presentation session is intended to be an opportunity for the participants to acoount for their writing, as well as a time to put whatever argumentation, validation, and confirmation they have written to test.

On the first round, or the preliminary round, the representatives from all regencies/provinces take part in the competition. They are gathered in a room and are required to write a popular-academic paper with one big theme prepared by the Panel of Judge. Each participant is free to formulate their own title, as long as the paper refers to the big theme. The themes prepared for M2IQ are relevant with the current issues in the society, including environmental, education, social welfare, and work ethic issues.

After the qualification round, the Panel of Judges will select 12 participants, 6 males and 6 females, with the highest score to participate in the semifinal round. In the semifinal round, they are once more required to write a paper using the same big theme, but with different topic.

Six participants, three males and three females with the highest score, from the semifinal round will compete in the final round. All participants in this final round have to present their paper in front of the Panel of Judges. Since M2IQ is essentially a writing competition, not a speech competition, this 
presentation only represents 15 percent of the total score the participants will get. The final score of this round is the accumulation of the score of semifinal writing and the $15 \%$ score of presentation.

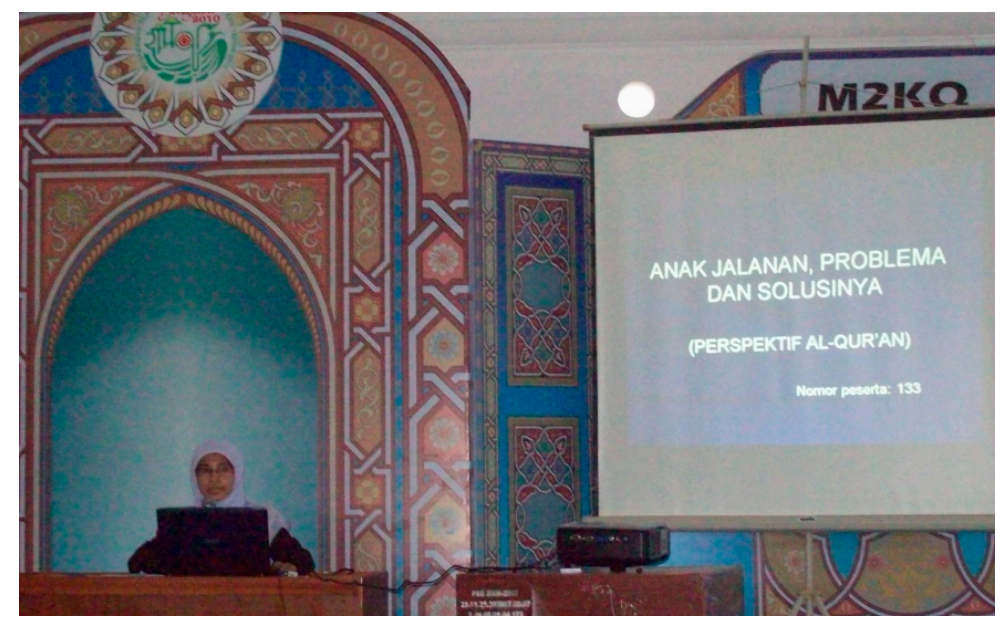

Remark:

A finalist of Musabaqah Makalah Ilmiah Al-Qurân (Al-Qurân Academic Writing Competition) is presenting her paper in front of the Panel of Judges (Photo: anonymous)

To put it simply, the overview of the competition can be seen in the following table (assuming that the competition is joined by 66 participants from all 33 provinces in Indonesia):

\begin{tabular}{|l|l|l|l|l|}
\hline Day & Time & Activities & Participants & Notes \\
\hline I & $08.00-17.00$ & Preliminary Round & 33 people & Males \\
\hline II & $08.00-17.00$ & Preliminary Round & 33 people & Females \\
\hline III & $08.00-19.00$ & Assessment & - & Panel of Judges \\
\hline IV & $08.00-16.00$ & Semifinal Round & 12 people & Males/Females \\
\hline V & $09.00-11.00$ & Final Round/Presentasi & 6 people & Males/Females \\
\hline
\end{tabular}

Source: M2IQ Manual (2012)

Then, how does the Panel of Judges determine the winner of M2IQ? Essentially, M2IQ combines two important skills of the participants: the academic sophistication and the technical writing skill. These two skills are formulated into variables of assessment that include:

Firstly, the weight of the material/content variable is represented by several indicators; including how relevant the title of the paper with the big theme is, how much worth and how current the ideas are, the extent to which the participant explore the content of Al-Qurân, and how broad the participants' perspectives are. Secondly, the variable of grammar and style is indicated by the correct grammar, the accuracy of punctuation, the appropriateness of language, and diction and expressions. Thirdly, the variable of logic and organization of messages is indicated by the coherence and consistence, the quality of ideas, the systematic organization of ideas, and the flow of the writing. The final variable is the resourcefulness of references, indicated by the use of sufficient and relevant sources, the use of main sources (not ad hoc sources), and the range of references (including those in foreign languages).

The 'sound' of Al-Qurân in M2IQ cannot be measure from the perspective of other MTQ domains. Al-Qurân is considered to have a voice ('sound') if it can relate to the social reality. Al-Qurân not only should be recited beautifully, it also has to be able to solve problems of humanity. It is a source of knowledge that still needs thousands and thousands attempts to interpret properly. However, those interpretations are of no use if Al-Qurân is only viewed as pages and pages of verses to satisfy the ears; 
not as teachings and principles that need to be brought to life among the people.

M2IQ tests participants' intelligence by seeing how they position Al-Qurân as a tool to dissect social reality to find the solutions for social problems in the local, national, and global levels. To see and relate how a statement in Al-Qurân can be relevant with a social fact, the participants need to have sharp observational skill. They need to be careful and thorough in choosing the appropriate verses in Al-Qurân to suit the social problem. They need to be smart and be true in interpreting the verses in transformative way so that Al-Qurân can really be the source of enlightenment for the whole world.

Technically, M2IQ offers a creative activity that can improve the skills and capabilities of the participants. This creative activity results in very valuable works; not only they have physical forms; they also can be sources of references for people to see how Al-Qurân is still relevant to solve today's problems. So far, M2IQ has created dozens of books; all of which are available for public. The books contain the compilation of M2IQ participants' writings. The books created through M2IQ, among others, are: 1. Al-Qurân Kitab Kehidupan (Al-Qurân, the Book of Life); 2. Al-Qurân Kitab Kesalehan Sosial (Al-Qurân, the Book of Social Piousness); 3. Pengembangan Pendidikan Berbasis Umat (The Development of PeopleBased Education); 4. Pemberdayaan Ekonomi Berbasis Umat (The Empowerment of People-Based Economy); 5. Transformasi Sosial Berbasis kearifan Lokal (Social Transformation Based on Local Wisdom); 6. Samudera Al-Qurân: Bersama Al-Qurân Menyelami Kehidupan (The Sea of Al-Qurân: Swimming in Life with Al-Qurân); 7. Kesalehan Multikultural: Menelusuri Nilai-nilai Al-Qurân dalam Praksis Budaya Lokal (Multicultural Piousness: Exploring the Values of Al-Qurân and the Practices of Local Culture); 8.AlQurân Kitab Ramah Lingkungan (Al-Qurân, an Environment-Friendly Scriptures), 9. Al-Qurân Inspirasi Kehidupan (Al-Qurân, Life Inspiration).

The emergence of M2IQ in the MTQ event answers the doubts of many people who criticize the tradition of MTQ in Indonesia. Beautiful reciting of Al-Qurân is no longer able to hold their attention, even after so much money is spent to prepare the event. The participation of many people in MTQ, which is considered one of the religious affairs, do not dissipate the dissatisfaction of these people. One of the reasons for their critiques and dissatisfaction is the apparent imbalance between the amounts of money spent with the lack of parameters to measure the success of the development of people's religiosity; particularly, those who have won the competition.

According to Roni Tabroni (2008), when the implementation of MTQ diverts from the mainstream of oral tradition, M2IQ succeeds to provide a real evidence of the usefulness of this competition. Although every activity has the potentials to be imperfect, M2IQ in general can respond to people's yearning of real works that people can enjoy and that leave their prints in history.

M2IQ is relatively unpopular among the participants of MTQ. It is difficult to find cadres or participants for this field of competition. Until now, there has not been many Islamic schools that can satisfy the need of M2IQ. This is another difference between M2IQ and other fields of MTQ. On the other domains, like tilawah, tafsir, tahfizh, khat, and syarhil, majority of the participants come from Islamic schools, while the participants of M2IQ generally come from Islamic Universities.

M2IQ, like any other domain of MTQ, is intended to give voice to Al-Qurân, so that it can be understood and practiced by the Moslem society. To put it simply, a lot of people have difficulties in translating the objective of 'to give a voice to Al-Qurân' in the context of M2IQ. This is what makes it so difficult to find cadres or participants for this competition. Even the elites of MTQ still have difficulties to formulate a working definition and parameter for this. How, and to what extent, can we determine that Al-Qurân does have a voice when it is put in writing?

The difficulties in understanding M2IQ are understandable, however. For tens of years MTQ tradition translates 'to give a voice' as 'sound that other people can hear'. Not only that; the sounds are regulated with so many rules. Since these same rules cannot be applied to measure 'the voice of AlQurân' in M2IQ, the difficulties arise.

The emergence of Al-Qurân Content Writing Competition, according to Faisal AD, is not a simple matter. It was born amidst the intellectual poverty of Moslems in Indonesia. It was intended to accelerate 
the development of Moslems, in West Java Province and in Indonesia. As a foundation of Moslems' intellectuality, M2IQ becomes an alternative driving force as well as a motivator to facilitate young Moslems to produce real works in the academic world with a religious touch.

Since M2IQ is initiated in MTQ, there is some kind of empowerment of local potentials in the society. The empowerment of young intellectuals, who mostly come from Islamic schools or universities, has been a unique and special thing for the intellectual and academic fields in Indonesia. Amidst the empowerment of young Moslems, the paradigm of public development is put into effect through these young agents of change and progress, born from the local potentials in the society.

Considering this, it is time to publish and socialize other local potentials as the solution to solve the intellectual crisis in Indonesia. It means that a transformative effort is needed to drive the society to move faster in filling the intellectual void with religious writings.

The axiology base of contemporary Islamic thinking makes M2IQ a place to be creative as well as a media to create and develop young Moslem intellectuals who are fully capable of transforming Islamic teachings, both orally and in writing. From the epistemology perspective, there is a strong will and hope to intellectually meet previous Moslem scholars through the compilation and publication of the best writings of M2IQ participants. This will carry on the intellectual movement of Islam.

The applicative-contributive value of M2IQ is the realization of the spirit of Al-Qur'ân in the local and national context. This is evident in the themes chosen for the competition and in the publication of the written works. In M2IQ, the participants' creativity to think, reconstruct, and deconstruct the interpretations of Al-Qur' ân teachings, related with the local and national contexts of culture, economy, social, and politics, has produced dozens of books.

The bigger goal of M2IQ is to instill and adjust the ways of Islamic diversity with the culture and tradition of Indonesia. This is in line with Quraish Shihab (2002: 18) who quotes M.B. Hooker, Robert Hefner, John L. Esposito, and William Liddle, to say that the existence of Islam in Indonesia is very specific, in which its intellectual, cultural, social, and political expressions may be, and indeed are, different from the expressions of Islam in other countries. Furthermore, Richard Bulliet notes that "it is the time to view Islam from the perspectives of Jakarta, Kuala Lumpur, or Teheran, not from Baghdad, Damascus, or Cairo' (Hidayat and Gaus, 2006).

Through M2IQ, young Moslems are prepared and equipped to be strong actors of civilization. They will put their thinking in the forms of written artifacts. As has been stated, written thoughts are more everlasting than their oral forms.

This competition is only the start. Young Moslems will be ready to think and analyze the reality in their society. They will be ready to refer to Al-Qurân verses to solve the problems of society, and put their thinking in written form. They spread Islam through writing, providing solutions that will be useful for the public in general.

Considering the great impacts and contributions of M2IQ, it can be considered as a form of 'leap of faith'. Kierkegard (Kompas, 29 April 2010) defines 'leap of faith' as a desire to get closer to God with passionate infinity. M2IQ formulates its leap of faith by producing written works, as a way to get close to God.

M2IQ indicates the birth of new tradition in the world of dakwah in Indonesia. M2IQ revive the tradition that has been initiated by ulama centuries ago, which faded away in the last couple of centuries. Through M2IQ, the tradition is being reborn.

In Islam, we know names and remember events that are inseparable from books. We know AlGazali, Ibnu Rusyd, Ibnu Sina, Syaikh 'Id, Imam Syafii and others with their magnum opus works. We know how they show the beauty and greatness of Islam through their writings. We also know that Islamic culture is built by those who have deep passion towards books.

Here is where M2IQ plays a role. It is born from the realization that Islamic civilization is inseparable from the culture of writings. Considering that it is hard to find new generation of thinkerwriter to continue the culture of writing and the Islamic civilization, M2IQ becomes a great effort to 
further the spirit and culture of Islamic literacy. Books are written and compiled because Islamic civilization is a civilization built from books and writings.

Attempting dakwah through writing is an effort to make dakwah everlasting. Writing is recording, recording is immortalizing. Written dakwah is a visionary method of dakwah, it is undeniable. Therefore, the idea to write the meaning, interpretation, and content of Al-Qurân, as is shown in M2IQ, is a great transformation of dakwah. M2IQ is a concrete attempt to spread the beauty and greatness of Al-Qurân, through books.

\section{Conclusion}

The emergence of Musabaqah Makalah llmiah Al-Qurân (M2IQ/Al-Qurân Academic Writing Competition) in the MTQ event is a cultural transformation of dakwah in Indonesia. It is a cultural response for the tradition of oral preaching that has been the major form of dakwah in Islamic communities. The method of dakwah in M2IQ is dakwah through writing. In this field of competition, the participants or contestants are required to explore the verses in Al-Qurân so that those verses 'exist and live' among the Moslem society. Therefore, the existence of M2IQ is an improvement of the methods of dakwah as well as an enrichment of the fields being contested in MTQ event. In other words, Al-Qurân Academic Writing Competition has widened the spectrum of Al-Qurân spreading through written dakwah. The Al-Qurân Academic Writing Competition has revived the tradition of previous ulama (Islamic scholars) who explored and poured their Qurânic thoughts and ideas in monumental writings. M2IQ also contributes in facilitating the development and growth of a more qualitative, more creative, more motivating, and more energetic culture among the Moslem societies, i.e. the tradition of writing. Dozens, even hundreds, of books; which are widely and publicly distributed, are created through M2IQ. Thus, M2IQ has accentuated the intellectual aspect and added an academic weight to the whole implementation of Musabaqah Tilawatil Qurân in Indonesia.

\section{References}

1. Adi, P. 2010. “Eksistensialisme Antara Kierkegard dan Sartre".Kompas, 29 April.

2. Bahrudin dan Kumaidi. 2014. "Model Asesmen Musabaqah Tilawatil Qurân (MTQ) Cabang Tilawah", Jurnal Penelitian dan Evaluasi Pendidikan, Vol. 18, No. 2, p 153-167.

3. Faisal, M.A.A.D. 2008. "Asep Saeful Muhtadi + Visi Qurâni = M2KQ, dalam Safei, Kucari Jalan Terba(l)ik. Bandung: Insan Komunika, p. 230-248.

4. Fealy, G and White, S. 2008. Expressing Islam: Religious Life and Politics in Indonesia, eds Greg Fealy and Sally White, Singapore, Institute of Southeast Asian Studies, pp 80-94.

5. Frishkopf, M. (2007).Mediated Qurânic Recitation and the Contestation of Islam Contemporary Egypt. Diakses tanggal 20 Juli 2015 dari http://www.islam world.net/historic.

6. Hidayat, KdanGaus, A.A.F. (eds). 2006. Menjadi Indonesia: 13 Abad Eksistesi Islam di Bumi Nusantara. Bandung: PT. Mizan Media Utama.Hooker, M.B. 2002.Islam Mazhab Indonesia: Fatwa-Fatwa dan Perubahan Sosial, Jakarta: Teraju.

7. Makdisi, G.A. 2005. Cita Humanisme Islam: Panorama Kebangkitan Intelektual dan Budaya Islam dan Pengaruhnya terhadap Renaisans Barat, terj. A. Syamsu Rizal \& Nur Hidayah, Yogyakarta: PT. Serambi Ilmu Semesta.

8. Mariana, A. 2008. “Transformasi Kultural ala M2KQ", dalam Safei, Kucari Jalan Terba(l)ik. Bandung: Insan Komunika, p. 202-209.

9. Millie, J.P., 2008, "Spiritual Meal" or Ongoing Project? The Dillema of Dakwah Oratory", in Expressing Islam: Religious Life and Politics in Indonesia, eds Greg Fealy and Sally White, Singapore, Institute of Southeast Asian Studies, pp 80-94. 
10. Millie, J.P. 2008. The People's Religion: The Sermons of A.F. Ghazali, A Collection of Excerpts from Sermons by A.F. Ghazali: One of The Most Beloved Preachers amongst the Sundanese Ethnic group of West Java. Bandung Indonesia: Cupumanik Publishing.

11. anonymous

12. Pahdepie, F. 2008. "M2KQ in Moi Demonstrata”, dalam Safei (ed), Kucari Jalan Terba(l)ik. Bandung: Insan Komunika, p. 178-187.

13. Rasmussen, A.K. 2010.Women's Voice, the Recited Qurân, and Islamic Music in Indonesia. Barkeley and Los Angeles: University of California Press.

14. anonymous

15. Shamim al-Shidiqi, 1989, Methodology of Da'wah, New York, The Forum for Islamic Work.

16. Shihab, M.Q., 2002. Wawasan Al-QurânJakarta: Lentera Hati.

17. Tabroni, R. 2008. "M2KQ Peninggalan Peradaban Terkini”, dalam Safei (ed), Kucari Jalan Terba(l)ik. Bandung: Insan Komunika, p. 195-201.

18. Tim LPTQ. 2010. Pedoman Musabaqah Al-Qurân 2010. Jakarta: Lembaga Pengembangan Tilawatil Qurân Tingkat Nasional.

19. Tim LPTQ Jabar. 2012. Manual M2KQ. Bandung: Lembaga Pengembangan Tilawatil Qurân Jawa Barat.

(C) 2016 by the author; licensee Preprints, Basel, Switzerland. This article is an open access article distributed under the terms and conditions of the Creative Commons by Attribution (CC-BY) license (http://creativecommons.org/licenses/by/4.0/). 